\title{
Incidence and pathogenesis of megaloblastic erythropoiesis in multiple myeloma
}

\author{
A. V. HOFFBRAND, ${ }^{1}$ J. R. HOBBS, S. KREMENCHUZKY, AND D. L. MOLLIN \\ From the Departments of Haematology and Chemical Pathology, Royal Postgradute Medical School, \\ Ducane Road, London, and the Medical Research Council Group for Investigation \\ into Megaloblastic and Sideroblastic Anaemias
}

SYNOPSIS Intermediate megaloblastic changes occurred in six $(19 \%)$ of 32 patients with multiple myeloma and trivial megaloblastic changes in a further ten $(31 \%)$. Folate deficiency was the predominant cause of these changes and in at least two patients was sufficiently severe to contribute to anaemia. Folate deficiency appeared to be due to excess folate utilization by the tumour and was related to the amount of paraprotein produced daily.

Five of the 32 patients had subnormal serum $B_{12}$ levels. Reduction in the serum $B_{12}$ level was related to the reduction in the normal circulating immunoglobulins and occurred despite normal $B_{12}$ absorption. Possible explanations for this finding are discussed.

Subnormal serum vitamin $\mathbf{B}_{12}$ concentrations have been reported in patients with multiple myeloma by a number of authors (Mollin and Ross, 1952; Mandema, 1956; Mandema, Faber, de Vries, and Nieweg, 1956; Killander and Larsson, 1962; Larsson, 1962; Forshaw, 1963; Hansen, 1964). In some of these patients megaloblastic anaemia was also observed and in the patients of Mandema (1956), in two patients of Larsson (1962), and in the patient of Forshaw (1963) the anaemia responded to large doses of vitamin $B_{12}$. The anaemia in another patient of Larsson (1962) and the patient of Bichel (1964) responded to liver therapy.

Nonetheless, true Addisonian pernicious anaemia appears to be rare in myeloma and it has only been established by the demonstration of histamine-fast achlorhydria associated with malabsorption of vitamin $B_{12}$ corrected by intrinsic factor in three patients (cases 2, 3, and 5 of Larsson, 1962). The cause of subnormal serum $B_{12}$ concentrations in patients with myeloma without pernicious anaemia is uncertain. It has been suggested that they are due to malabsorption of vitamin $\mathbf{B}_{12}$ associated with bacterial contamination of the small intestine (Larsson, 1962) or to excess $B_{12}$ utilization by the tumour (Mandema et al., 1956; Killander and

${ }^{1}$ Present address: Department of Haematology, St. Bartholomew's Hospital, London E.C.1.

Received for publication 29 March 1967.
Larsson, 1962; van Dommelen, Olie, and Slagboom, 1964).

The present study was undertaken to determine the incidence, severity, and cause of $\mathrm{B}_{12}$ deficiency in patients with multiple myeloma. Since megaloblastic anaemia in other conditions in which there is proliferation of primitive tissue is almost invariably due to folate deficiency (Swendseid, Swanson, Meyers, and Bethell, 1952; Girdwood, 1953), the incidence and pathogenesis of folate deficiency was investigated in the same group of patients and this paper reports the results of both studies.

\section{PATIENTS STUDIED}

Thirty-two randomly selected patients with myeloma were studied. Their ages ranged from 42 to 81 (mean 67 years) and they included 17 males and 15 females. All the patients were investigated while in hospital for investigation or treatment.

In each patient, the diagnosis was made because the patient showed clinical and/or radiological evidence of bone lesions of the myeloma type, abnormal and increased numbers of plasma cells in the bone marrow, a characteristic narrow 'monoclonal' band on electrophoresis of the serum proteins and/or Bence-Jones proteinuria. Ten patients were studied at the time myeloma was first diagnosed, and in the remaining 22 patients myeloma was known to have been present from two months to nine years previously. Fifteen patients were receiving no specific therapy, seven patients were receiving melphelan (from 
0.25 to $4 \mathrm{mg}$. daily), one patient urethane ( $3 \mathrm{mg}$. daily), one patient prednisone ( $5 \mathrm{mg}$. b.d.), and eight were having deep $x$-ray therapy for bone lesions. In the patients on cytotoxic drugs, serum for microbiological assay was taken at least 24 hours after the last dose of the drug.

\section{METHODS}

SERUM VITAMIN B $_{12}$ CONCENTRATIONS These were determined by microbiological assay using the $\mathrm{z}$ strains of Euglena gracilis as test organism as described by Anderson (1964) with a normal range from 160 to $925 \mu \mu \mathrm{g}$. per $\mathrm{ml}$.

VITAMIN $\mathbf{B}_{12}$ ABSORPTION This was measured by the urinary excretion method of Schilling (1953) using an oral dose of $1 \mu \mathrm{g}$. radioactive ${ }^{58} \mathrm{Co}-\mathrm{B}_{12}$ and an intramuscular flushing dose of $1,000 \mu \mathrm{g}$. non-radioactive $B_{12}$. Normal subjects excrete more than $10 \%$ of the oral dose in 24 hours and patients with Addisonian pernicious anaemia excrete less than $5 \%$ and usually less than $2.5 \%$ in 24 hours.

SERUM FOLATE CONCENTRATIONS These were estimated by microbiological assay using Lactobacillus casei as test organism as described by Waters and Mollins (1961). The normal range is from 6.0 to $21.0 \mathrm{~m} \mu \mathrm{g}$. per $\mathrm{ml}$.

SERUM MYELOMA PARAPROTEINS These were recognized by their narrow 'monoclonal' electrophoretic mobility, or socalled ' $M$ ' band. They were identified by immunoelectrophoresis as $\gamma_{\mathrm{G}}, \gamma_{\mathrm{A}}$, or Bence-Jones protein. Their light chains were shown to be of one type only and identified as $\mathrm{K}$ (Kappa) or L (Lambda) (Nomenclature of Human Immunoglobulins, Bull. Wld Hlth Org., 1964).

TOTAL SERUM PROTEIN CONCENTRATIONS These were estimated by a Biuret method calibrated against Armour standard bovine albumin. Using this method, $\gamma_{\mathrm{G}}$ globulin yields $3 \%$ less colour, and $\gamma_{\mathrm{A}}$ globulin $8 \%$ less colour than the same weight of albumin but no correction has been made, the error being slight, since, in all but one patient, the concentration of myeloma $(\mathrm{M})$ protein in the serum was less than half the total serum protein concentration. The proportion of $M$ protein in the serum proteins was estimated after electrophoresis on cellulose acetate using the dye amidoschwarz $10 \mathrm{~B}$ as colouring agent. This dye yields near uniform uptakes for the same weights of albumin, $\gamma_{\mathrm{G}}$, and $\gamma_{\mathrm{A}}$ globulins and recoveries of pure added fractions are reliable to within $0.2 \mathrm{~g}$. per $100 \mathrm{ml}$. (Hobbs, 1965). The concentration of $M$ protein was then calculated from the known total serum protein concentration.

URINARY PROTEIN was estimated by a Biuret method after overnight precipitation in $10 \%$ trichloracetic acid and redissolving the precipitate in $\mathrm{N}$ sodium hydroxide. The content of $\mathbf{M}$ protein in urine was estimated after electrophoresis of concentrated urine by the method used to estimate serum $\mathbf{M}$ protein.

DAILY PRODUCTION OF M PROTEIN An estimate of the daily output of $M$ protein was made using the following assumptions. It has been shown that $\gamma_{\mathrm{A}}$ myeloma globulins have a shorter half life (mean 6.4 days) than $\gamma_{G}$ myeloma globulins (mean 11.6 days) (Drivsholm, 1964). For the same serum concentration, therefore, $\gamma_{\mathrm{A}}$ protein has a faster turnover (estimated as $10.8 \%$ of the total pool) than $\gamma_{\mathrm{G}}$ protein (estimated as $6 \%$ of the total pool). In order to compare our patients, we have arbitrarily considered them all to be $71 \mathrm{~kg}$. in weight, with a plasma volume of $50.7 \mathrm{ml}$. per $\mathrm{kg}$., with the plasma containing $71 \%$ of the total pool of myeloma globulin (averages of available data in myeloma patients, Gabuzda, 1962). Thus, for a given serum concentration of myeloma globulin, $\mathbf{M ~ g}$. per $100 \mathrm{ml}$, the total pool would be $\frac{\mathrm{M}}{100} \times 71 \times 50.7 \times$ $\frac{100}{71}=50.7 \mathrm{M}$ g., and for patients in equilibrium, the average daily productions of $\gamma_{A}$ would be $10.8 \%$ of $50.7 \mathrm{M}=5.5 \mathrm{Mg}$., and of $\gamma_{\mathrm{G}} 6 \%$ of $50.7 \mathrm{M}=3.0 \mathrm{Mg}$.

In order to obtain the total daily $\mathbf{M}$ protein production, the daily Bence-Jones protein loss in the urine was measured, corrected to $71 \mathrm{~kg}$. from the patient's body weight, and added to the production of $\mathbf{M}$ protein, calculated above.

It is recognized that this calculation only gives an approximate value since plasma and total body pools and the half life of the plasma proteins all show individual variation. Nevertheless, this variation is mostly less than $\pm 25 \%$ of the taken means.

LOSS OF NORMAL HUMORAL IMMUNITY This was estimated by measuring the concentration of the serum immunoglobulins $\left(\gamma_{G}, \gamma_{A}\right.$, and $\left.\gamma_{M}\right)$ and taking their average, each expressed as a percentage of the normal mean, e.g., case FB had serum concentrations, $\gamma_{\mathrm{G}} 75 \%, \gamma_{\mathrm{A}} 70 \%$, and $\gamma_{M} 70 \%$ of normal, giving an average $72 \%$ of the normal immunoglobulin concentration.

\section{HAEMATOLOGICAL FINDINGS}

INCIDENCE OF MEGALOBLASTIC HAEMOPOIESIS In Table I, patients are divided according to whether or not they show megaloblastic change in the bone marrow. Six (19\%) of the 32 patients (group I) showed intermediate megaloblastic changes(Dacie and White, 1949) and a further $10(31 \%)$ patients (group II) showed trivial megaloblastic changes. The remaining 16 patients (group III) had entirely normoblastic bone marrows. None of the patients showed the florid megaloblastic changes seen in severely anaemic patients with uncomplicated megaloblastic anaemia.

The appearances of the stained peripheral blood films were largely, but not invariably, consistent with these bone marrow findings. Macrocytes and hypersegmented polymorphs (polymorphs with more than five nuclear lobes) were more frequent in the stained peripheral blood films of group I, less frequent in those of group II, and rarely present in those of group III.

RELATION OF MEGALOBLASTIC HAEMOPOIESIS TO OTHER HAEMATOLOGICAL FINDINGS Nearly all (30) of the 32 patients were anaemic at the time of the present studies (Table I). There was no direct correlation 
TABLE I

\begin{tabular}{|c|c|c|c|c|c|c|c|c|c|c|}
\hline & & & MATOLOG & CAL AND & BIOCHEMIC & CAL FINDINC & GS IN THE 32 & ATIENTS & & \\
\hline Group & $\begin{array}{l}\text { Case } \\
\text { No. }\end{array}$ & $\begin{array}{l}\text { Agel } \\
\text { Sex }\end{array}$ & $\begin{array}{l}H b \\
(g . / 100 \mathrm{ml} .)\end{array}$ & $\begin{array}{l}\text { Serum } B_{12} \\
(\mu \mu g . / m l .)\end{array}$ & $\begin{array}{l}\text { Serum } \\
\text { Folate } \\
(m \mu g . / m l .)\end{array}$ & $\begin{array}{l}\text { Serum } M \\
\text { Protein } \\
(\mathrm{g} . / 100 \mathrm{ml} .)\end{array}$ & $\begin{array}{l}\text { Immunological } \\
\text { Type of } M\end{array}$ & $\begin{array}{l}\text { Urine } \\
\text { Bence-Jones } \\
\text { (g./day) }\end{array}$ & $\begin{array}{l}\text { Calculated } \\
\text { Total } \\
\text { Paraprotein } \\
\text { Production } \\
\text { (g./day) }\end{array}$ & $\begin{array}{l}\text { Remaining } \\
\text { Immunoglobulins } \\
\text { (mean \% } \\
\text { normal mean) }\end{array}$ \\
\hline $\begin{array}{l}\text { I } \\
\text { (intermediate } \\
\text { megaloblastic } \\
\text { changes) }\end{array}$ & $\begin{array}{l}1 \\
2 \\
3 \\
4 \\
5 \\
6\end{array}$ & $\begin{array}{l}53 / \mathrm{F} \\
66 / \mathrm{M} \\
74 / \mathrm{F} \\
54 / \mathrm{M} \\
81 / \mathrm{F} \\
66 / \mathrm{M}\end{array}$ & $\begin{array}{l}8 \cdot 3 \\
7 \cdot 5 \\
7 \cdot 2 \\
5 \cdot 1 \\
6 \cdot 4 \\
7 \cdot 0\end{array}$ & $\begin{array}{l}110 \\
120 \\
170 \\
370 \\
560 \\
610\end{array}$ & $\begin{array}{l}3.5 \\
2.5 \\
3.5 \\
1.7 \\
1.5 \\
4.4\end{array}$ & $\begin{array}{l}6 \cdot 2 \\
7 \cdot 0 \\
3 \cdot 1 \\
4 \cdot 4 \\
4 \cdot 7 \\
2 \cdot 1\end{array}$ & $\begin{array}{l}\mathbf{L} \\
\mathbf{K} \\
\mathbf{K} \\
\mathbf{A L} \\
\mathbf{L} \\
\mathbf{L}\end{array}$ & $\begin{array}{c}0 \\
0 \\
11 \cdot 6 \\
0 \\
24 \cdot 8 \\
12 \cdot 3\end{array}$ & $\begin{array}{l}18 \cdot 6 \\
21 \cdot 0 \\
20 \cdot 9 \\
24 \cdot 2 \\
24 \cdot 8 \\
12 \cdot 3\end{array}$ & $\begin{array}{r}8 \\
3 \\
6 \\
32 \\
75 \\
40\end{array}$ \\
\hline $\begin{array}{l}\text { II } \\
\text { (trivial } \\
\text { megaloblastic } \\
\text { changes) }\end{array}$ & $\begin{array}{r}7 \\
8 \\
9 \\
10 \\
11 \\
12 \\
13 \\
14 \\
15 \\
16\end{array}$ & $\begin{array}{l}63 / \mathrm{M} \\
75 / \mathrm{F} \\
59 / \mathrm{M} \\
73 / \mathrm{F} \\
62 / \mathrm{M} \\
60 / \mathrm{M} \\
75 / \mathrm{M} \\
51 / \mathrm{F} \\
71 / \mathrm{M} \\
42 / \mathrm{M}\end{array}$ & $\begin{array}{r}7 \cdot 2 \\
10.0 \\
5.5 \\
10.5 \\
9.6 \\
12.0 \\
11.8 \\
10.6 \\
13.4 \\
6.1\end{array}$ & $\begin{array}{l}135 \\
145 \\
150 \\
210 \\
230 \\
255 \\
280 \\
350 \\
480 \\
480\end{array}$ & $\begin{array}{r}3.5 \\
11.2 \\
3.0 \\
3.9 \\
3.6 \\
2.9 \\
4.5 \\
4.7 \\
2.4 \\
5.5\end{array}$ & $\begin{array}{l}5 \cdot 7 \\
1 \cdot 6 \\
6 \cdot 2 \\
1 \cdot 4 \\
3 \cdot 0 \\
1 \cdot 8 \\
3 \cdot 3 \\
1 \cdot 3 \\
4 \cdot 1 \\
3 \cdot 7\end{array}$ & $\begin{array}{l}\mathbf{K} \\
\mathbf{K} \\
\mathbf{A K} \\
\mathbf{K} \\
\mathbf{K} \\
\mathbf{A K} \\
\mathbf{K} \\
\mathbf{A L} \\
\mathbf{A L} \\
\mathbf{K}\end{array}$ & $\begin{array}{l}0.4 \\
1.2 \\
0.5 \\
1.5 \\
0 \\
0.9 \\
0 \\
0 \\
3.6 \\
0\end{array}$ & $\begin{array}{r}17 \cdot 5 \\
6 \cdot 0 \\
35 \cdot 2 \\
6 \cdot 9 \\
9 \cdot 0 \\
11 \cdot 1 \\
9.9 \\
7 \cdot 2 \\
26 \cdot 2 \\
11 \cdot 1\end{array}$ & $\begin{array}{r}20 \\
8 \\
22 \\
19 \\
7 \\
68 \\
16 \\
95 \\
50 \\
12\end{array}$ \\
\hline $\begin{array}{l}\text { III } \\
\text { (normoblastic) }\end{array}$ & $\begin{array}{l}17 \\
18 \\
19 \\
20 \\
21 \\
22 \\
23 \\
24 \\
25 \\
26 \\
27 \\
28 \\
29 \\
30 \\
31 \\
32\end{array}$ & $\begin{array}{l}75 / \mathrm{F} \\
70 / \mathrm{M} \\
66 / \mathrm{M} \\
59 / \mathrm{M} \\
75 / \mathrm{F} \\
67 / \mathrm{F} \\
53 / \mathrm{M} \\
55 / \mathrm{F} \\
68 / \mathrm{M} \\
61 / \mathrm{F} \\
59 / \mathrm{F} \\
52 / \mathrm{M} \\
69 / \mathrm{F} \\
73 / \mathrm{F} \\
66 / \mathrm{F} \\
71 / \mathrm{M}\end{array}$ & $\begin{array}{r}10 \cdot 2 \\
14 \cdot 4 \\
13.0 \\
14 \cdot 8 \\
9.6 \\
11 \cdot 1 \\
12 \cdot 2 \\
8.9 \\
12 \cdot 4 \\
9.7 \\
9.9 \\
11 \cdot 5 \\
9.1 \\
9.8 \\
11 \cdot 4 \\
10.0\end{array}$ & $\begin{array}{l}175 \\
255 \\
270 \\
310 \\
320 \\
340 \\
385 \\
385 \\
440 \\
455 \\
490 \\
500 \\
500 \\
655 \\
750 \\
920\end{array}$ & $\begin{array}{l}3 \cdot 6 \\
4 \cdot 8 \\
3 \cdot 0 \\
7 \cdot 3 \\
5 \cdot 2 \\
6 \cdot 5 \\
5 \cdot 3 \\
8 \cdot 2 \\
7 \cdot 7 \\
4 \cdot 1 \\
4 \cdot 9 \\
2 \cdot 3 \\
4 \cdot 8 \\
4 \cdot 5 \\
5 \cdot 0 \\
4 \cdot 4\end{array}$ & $\begin{array}{l}4 \cdot 2 \\
4 \cdot 4 \\
3.6 \\
0.9 \\
3.7 \\
2.0 \\
1.9 \\
1 \cdot 2 \\
0.8 \\
3 \cdot 2 \\
2.5 \\
5.4 \\
0.0 \\
2.6 \\
0 \\
2.6\end{array}$ & $\begin{array}{l}\mathbf{A K} \\
\mathbf{L} \\
\mathbf{A K} \\
\mathbf{A K} \\
\mathbf{K} \\
\mathbf{K} \\
\mathbf{L} \\
\mathbf{K} \\
\mathbf{A K} \\
\mathbf{A L} \\
\mathbf{A K} \\
\mathbf{A K} \\
\mathbf{K} \\
\mathbf{K} \\
\mathbf{K} \\
\mathbf{K}\end{array}$ & $\begin{array}{l}0 \\
0 \\
0 \\
1 \cdot 4 \\
4 \cdot 8 \\
0 \\
0 \\
3 \cdot 5 \\
0 \\
0 \cdot 12 \\
0 \\
0 \\
5 \cdot 5 \\
4 \cdot 0 \\
4 \cdot 8 \\
0\end{array}$ & $\begin{array}{r}23 \cdot 1 \\
13 \cdot 2 \\
19.9 \\
5 \cdot 1 \\
17 \cdot 0 \\
6 \cdot 0 \\
5 \cdot 7 \\
7 \cdot 1 \\
4 \cdot 5 \\
18 \cdot 8 \\
13 \cdot 8 \\
29 \cdot 7 \\
5 \cdot 5 \\
11 \cdot 8 \\
4.8 \\
7 \cdot 8\end{array}$ & $\begin{array}{r}37 \\
25 \\
28 \\
18 \\
5 \\
10 \\
49 \\
17 \\
36 \\
56 \\
60 \\
65 \\
63 \\
65 \\
90 \\
60\end{array}$ \\
\hline
\end{tabular}

between the degree of anaemia and the severity of megaloblastic changes. However, the patients with intermediate megaloblastic changes (group I) were invariably severely anaemic and their mean haemoglobin concentration was lower than that of either of the other two groups. The mean platelet count was also lower in group I $(94,000$ per c. $\mathrm{mm}$.) than in groups II and III (173,000 and 211,000 per c. $\mathrm{mm}$. respectively), but the mean leucocyte counts were similar in all three groups.

\section{SERUM $B_{12}$ CONCENTRATIONS}

Five of the 32 patients had subnormal serum $B_{12}$ levels (Table I) and the mean serum $B_{12}$ level of the whole group (368 $\mu \mu \mathrm{g}$. per ml.) was significantly lower than that of a normal control group (472 $\mu \mu$ g. per ml.; Anderson, 1964) $(P<0.001)$. In none of the patients, however, was the serum $B_{12}$ level as low as in patients with overt pernicious anaemia (i.e., less than $100 \mu \mu \mathrm{g}$. per ml.; Anderson, 1964).

\section{SERUM FOLATE CONCENTRATIONS}

Twenty-six of the 32 patients had subnormal serum folate concentrations and in six these were within the range usually found in severe folate deficiency (i.e., less than $3.0 \mathrm{~m} \mu \mathrm{g}$. per $\mathrm{ml}$.; Hoffbrand, Newcombe, and Mollin, 1966).

On the basis of these serum $B_{12}$ and folate levels, folate deficiency appeared to be the predominant cause of megaloblastic changes since 11 of the 16 patients with megaloblastic changes had subnormal serum folate but normal serum $B_{12}$ levels; four had subnormal serum folate and $B_{12}$ levels, and only one (case 8) had a subnormal serum $B_{12}$ and normal serum folate level.

RESPONSES TO FOLIC ACID AND VITAMIN B $_{12}$ THERAPY

Despite the frequency of subnormal serum folate and $B_{12}$ levels, it is unlikely that deficiency of either vitamin contributed significantly to anaemia in more than one or two patients. The effect of folic acid and/ or $B_{12}$ therapy was studied in five of the six patients in group I and in four patients in group II. In group I, one patient (case 3 ) with megaloblastic changes due to folate deficiency showed a definite haematological improvement when given folic acid in large doses ( 5 mg. t.d.s. by mouth) (Fig. 1). In a second patient in this group, who also had folate deficiency, folic acid 


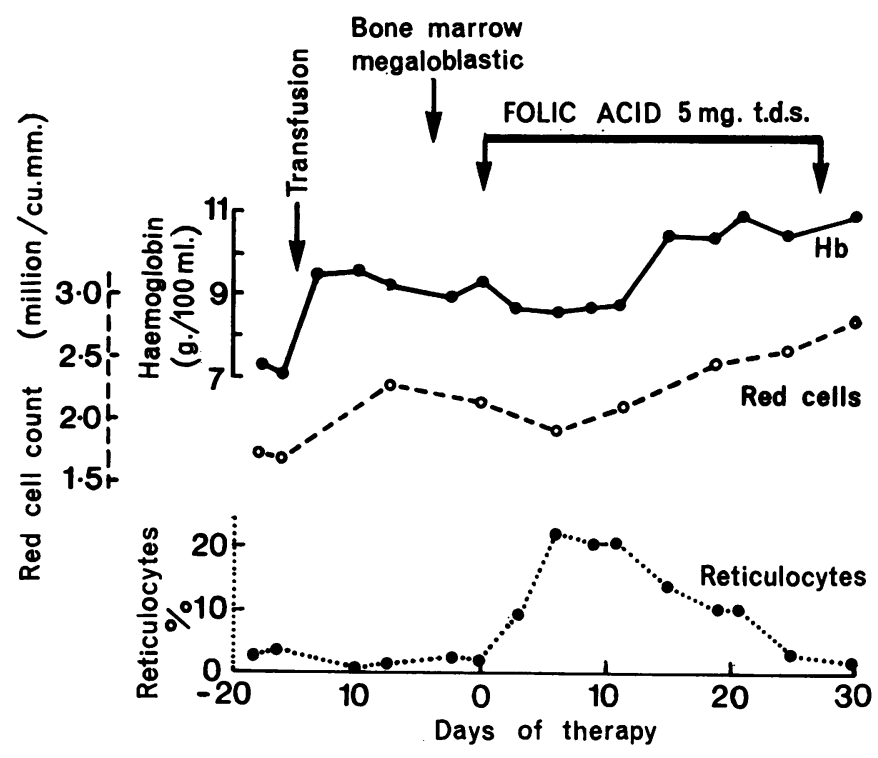

FIG. 1. The haematological response to folic acid in case 3.

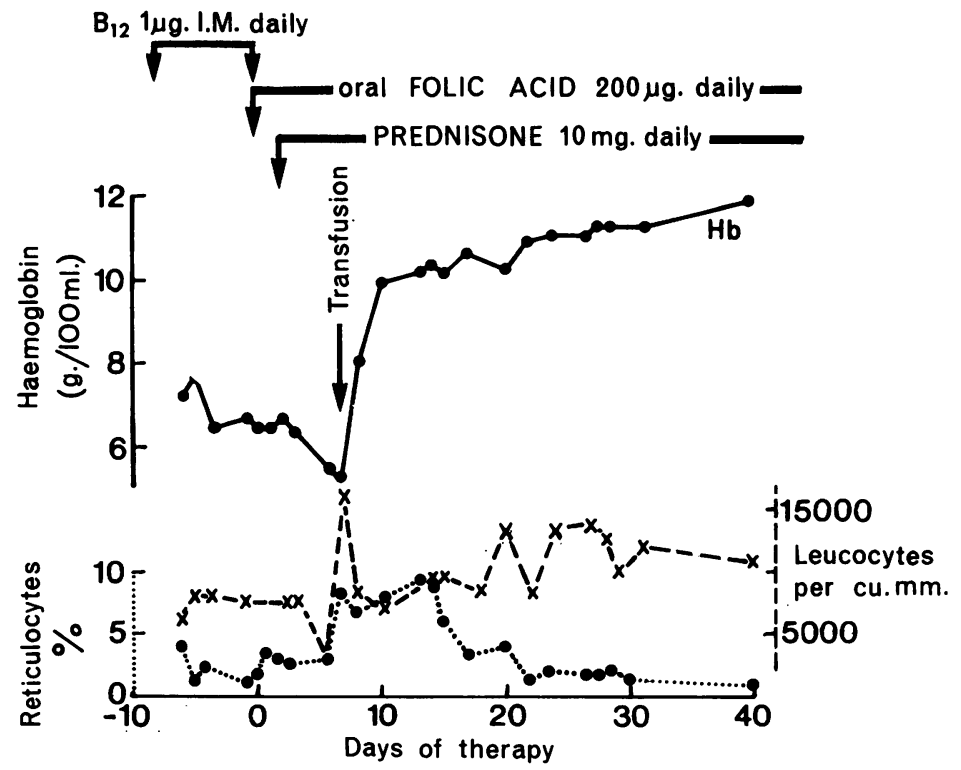

FIG. 2. The haematological response to folic acid and steroid therapy in case 6.

Bone marrow

K Megaloblastic $\rightarrow$ Normoblastic

therapy probably produced a haematological response, but the issue in this patient was obscured by coincidental steroid therapy and a blood transfusion (Fig. 2). There was no significant rise in haemoglobin, leucocyte, or platelet count or other haematological benefit from folic acid in cases 4 and 5 , and $B_{12}$ therapy $(100 \mu \mathrm{g}$. daily) in case 1 , though case 4 did show successive small reticulocyte responses to oral folic acid in physiological (200 $\mu \mathrm{g}$. daily) and then large $(5 \mathrm{mg}$. t.d.s.) doses. In the remaining patient in group I (case 2) the response to folic acid and/or $B_{12}$ therapy was not assessed.

As might be expected from the mildness of the megaloblastic changes in group II, none of the 
patients in this group given folic acid (cases 12 and 15) or $\mathrm{B}_{12}$ (cases 7 and 8 ) responded.

PATHOGENESIS OF THE SUBNORMAL SERUM B $_{12}$ LEVELS

RELATION OF SERUM $B_{12}$ LEVELS TO CHANGES IN PLASMA PROTEINS There was no correlation between the serum $B_{12}$ levels of the patients and their age, sex, length of history, type of treatment, degree of anaemia, serum concentration of globulin or myeloma protein or with their calculated daily paraprotein production. As shown in Fig. 3, however, the serum $\mathbf{B}_{12}$ levels tended to be lower in the patients with a greater degree of immuneparesis. The five patients with subnormal serum $\mathrm{B}_{12}$ levels had only $22 \%$ or less of the normal mean serum immunoglobulin concentration. Thirteen of the other 15 patients with serum $B_{12}$ levels less than $400 \mu \mu \mathrm{g}$. per ml. had less than $50 \%$ of normal mean immunoglobulin, whereas only three of the 12 patients with serum $B_{12}$ levels greater than $400 \mu \mu \mathrm{g}$. per $\mathrm{ml}$. had a reduction in mean immunoglobulin level to less than $50 \%$ of normal.

B $_{12}$ ABSORPTIONSTUDIES Schilling tests were performed in 12 patients including three (cases 1,7 , and 8 ) with subnormal serum $B_{12}$ levels. None of these 12 patients

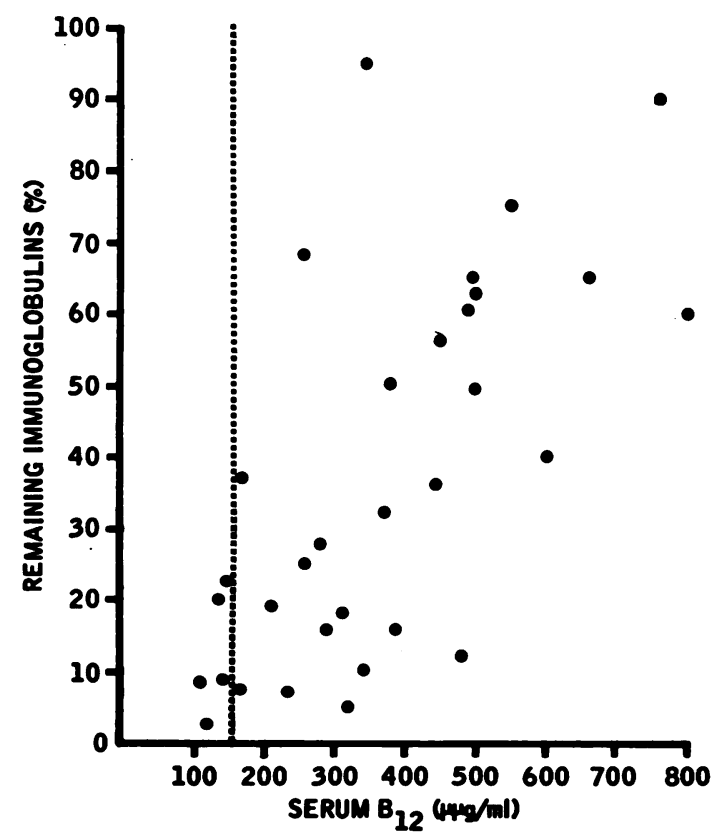

FIG. 3. The serum $B_{12}$ levels of the 32 patients plotted against their mean remaining immunoglobulin levels, expressed as a percentage of the normal mean. The vertical broken line is the lower limit of normal serum $B_{12}$ levels. had evidence of renal failure. The results are shown in Table II. In only one patient was $B_{12}$ absorption reduced to the range found in pernicious anaemia, and in this patient (case 13) the increased absorption with intrinsic factor was suboptimal. In four patients with only slightly reduced $\mathrm{B}_{12}$ absorption, the absorption with intrinsic factor was normal. The absorption of radioactive $B_{12}$ was within the normal range in the three patients with subnormal serum $B_{12}$ levels and in the other four patients tested.

TABLE II

SERUM $B_{12}$ LEVELS AND SCHILLING TEST RESULTS IN 12 PATIENTS

\begin{tabular}{|c|c|c|c|}
\hline \multirow[t]{2}{*}{ Case No. } & \multirow{2}{*}{$\begin{array}{l}\text { Serum } B_{12} \\
(\mu \mu \mathrm{g} . / \mathrm{ml} .)\end{array}$} & \multicolumn{2}{|c|}{$\begin{array}{l}\text { Schilling Test } \\
\text { (24hr. urinary excretion of } \\
\left.\text { radioactive }{ }^{58} \mathrm{Co}_{12} l \mu \mathrm{g} .\right)\end{array}$} \\
\hline & & Dose Alone & $\begin{array}{l}\text { Dose + Intrinsic } \\
\text { Factor }\end{array}$ \\
\hline 1 & 110 & 11.9 & 13.6 \\
\hline 7 & 135 & $14 \cdot 1$ & $10 \cdot 6$ \\
\hline 9 & 150 & $12 \cdot 1$ & 21.8 \\
\hline 19 & 270 & $5 \cdot 2$ & 11.4 \\
\hline 13 & 280 & 3.6 & 9.0 \\
\hline 20 & 300 & $8 \cdot 4$ & 14.8 \\
\hline 23 & 385 & 8.9 & $10 \cdot 6$ \\
\hline 16 & 480 & 7.0 & 10.5 \\
\hline 28 & 500 & $15 \cdot 1$ & - \\
\hline 6 & 610 & $15 \cdot 6$ & - \\
\hline 31 & 750 & $14 \cdot 1$ & - \\
\hline 32 & 920 & 12.5 & - \\
\hline
\end{tabular}

ANTIBODY STUDIES Tests for gastric parietal cell and intrinsic factor antibodies, carried out on four of the five patients with subnormal serum $B_{12}$ levels (cases 1 , 2,7 , and 8), were negative.

\section{PATHOGENESIS OF THE SUBNORMAL SERUM FOLATE LEVELS}

In contrast to the finding with serum $\mathrm{B}_{12}$ levels, there was a moderately good inverse correlation between the calculated daily paraprotein production of the patients and their serum folate concentrations, the patients with the greatest paraprotein production having the lowest serum folate levels (Fig. 4). On the other hand there is no relation between serum folate concentration and the degree of immuneparesis or the serum level of globulin or myeloma protein or with the age or sex of the patients, the length of history, or the type of therapy. In one patient with severe folate deficiency (case 6), the dietary folate intake was calculated (61 $\mu \mathrm{g}$. daily) and folic acid absorption was measured. Both were normal.

\section{DISCUSSION}

The results of these studies confirm those of previous workers (Toušek and Vortel, 1947; Heilmeyer and 


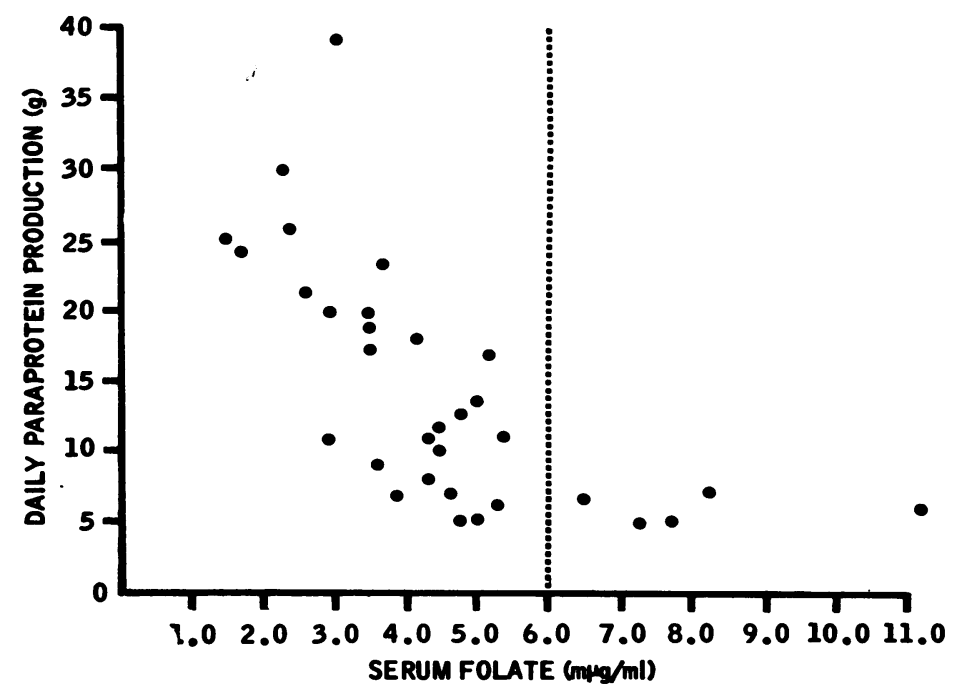

FIG. 4. The serum folate levels of the 32 patients plotted against their calculated daily paraprotein production. The vertical broken line is the lower limit of normal serum folate levels.

Begemann, 1951 ; Sandkühler, 1951 ; Mandema, 1956; Reisner, 1958; Forshaw, 1963) that megaloblastic changes are frequently present in patients with myeloma. In addition, they show that the predominant cause of these changes is folate deficiency. In an occasional patient studied here folate deficiency was sufficiently severe to contribute to anaemia but in the majority of the folate-deficient patients there was either no response to folic acid or the deficiency was too mild to be a cause of anaemia. Since there is a theoretical objection to giving folic acid to patients with malignant disease because it might increase the rate of growth of the tumour, it is probably advisable to reserve folic acid therapy in myeloma to patients who have clear evidence of severe deficiency and in whom anaemia or possibly thrombocytopenia are important features.

The main cause of folate deficiency in myeloma is likely to be increased folate utilization by the tumour. This is supported by the present finding of the lowest serum folate levels in the patients with the greatest paraprotein production. The latter may well be roughly related to the mass of tumour cell present (Nathans, Fahey, and Potter, 1958). Reduced dietary folate intake might also contribute to the deficiency in some of the patients since they almost invariably have anorexia.

The low serum $B_{12}$ levels in myeloma are more unexpected and also more difficult to explain. Subnormal serum $B_{12}$ levels are not usually found in generalized malignant diseases in which, in the absence of gastrointestinal involvement, serum $B_{12}$ levels are normal or elevated (Mollin and Ross, 1957).
A few of the patients with myeloma and $B_{12}$ deficiency reported by other authors had frank pernicious anaemia, but, as Larsson (1962) suggests, this may be a chance association. In the majority of patients with myeloma and subnormal serum $B_{12}$ levels, pernicious anaemia is not present, and in some, as in cases 1, 7, and 8 here, $B_{12}$ absorption is normal.

This is an unusual finding. Subnormal serum $\mathbf{B}_{12}$ levels with normal $B_{12}$ absorption occur in vegans (Wokes, Badenoch, and Sinclair, 1955), in some patients with severe megaloblastic anaemia due to folate deficiency (Mollin, Waters, and Harris, 1962), and in infants born to $\mathrm{B}_{12}$-deficient mothers (Lampkin, Shore, and Chadwick, 1966). It has also been reported in a single patient with $B_{12}$-dependent anaemia apparently due to defective plasma binding of $\mathrm{B}_{12}$ (Horrigan and Heinle, 1952) and it occurs rarely after partial gastrectomy (Deller and Witts, 1962). Killander and Larsson (1962) suggested that the subnormal $\mathrm{B}_{\mathbf{1 2}}$ levels in myeloma weremainly due to excess utilization of $B_{12}$ by the tumour, since in their study the lower serum $B_{12}$ levels occurred in the patients with the highest serum concentrations of myeloma protein. The present results do not confirm this. Rather they show that the reduction in serum $B_{12}$ level is related to the reduction in the normal circulating immunoglobulins. The three patients of Killander and Larsson all had $\gamma_{\mathrm{G}}$ myelomata and, although the authors do not comment on this, are therefore likely to have had severe immuneparesis (Hobbs, Slot, Campbell, Clein, Scott, Crowther, and Swan, 1966). It is of interest that $B_{12}$ deficiency is not infrequent in patients suffering from hypogamma- 
globulinaemia from causes other than myeloma (Klayman and Brandborg, 1955; Larsson, Hagelquist, and Cöster, 1961 ; Gibbs and Pryor, 1961 ; Lee, Jenkins, Hughes, and Kazantzis, 1964). Although Meyer, Bertcher, Cronkite, Suarez, Miller, Mulzac, and Olivarreta (1961) could not detect any reduction in the $B_{12}$-binding capacity in vitro of serum from patients with myeloma, this does not exclude reduction in the concentration of the endogenous $B_{12}$-binding protein in this condition. The relation between serum $B_{12}$ level and degree of immuneparesis found here could be explained if the low serum $B_{12}$ levels were due to a reduction in this endogenous serum $B_{12}$ binding protein (an $\alpha$ globulin) in parallel to the reduction in immunoglobulins.

Five patients with normal serum $B_{12}$ levels had subnormal serum $B_{12}$ absorption but in only one of them was the absorption as low as in pernicious anaemia. In all five absorption was significantly improved by intrinsic factor. These findings suggest reduced secretion of intrinsic factor in these patients but this is not an uncommon finding in patients of a similar age group. In Forshaw's (1963) patient whose serum $B_{12}$ level was just subnormal (120 $\mu \mu \mathrm{g}$. per ml.), $B_{12}$ absorption was at the lower limit of normal and improved significantly with intrinsic factor. In this patient, however, free gastric acid was present and a gastric biopsy was normal.

The present studies lend no support to the theory that $B_{12}$ deficiency in myeloma is due to bacterial contamination of the small intestine. In none was there severe reduction in $B_{12}$ absorption when this was tested with added intrinsic factor.

We wish to thank the physicians of the Hammersmith and St. Bartholomew's Hospitals for permission to study patients under their care.

In addition we are grateful to Dr. Deborah Doniach for the gastric antibody studies, and to Mr. J. Morgan, who performed many of the microbiological assays.

Dr. S. Kremenchuzky is in receipt of a grant from the Consejo Nacional de Investigaciones Científicasy Técncas, Argentina.

\section{REFERENCES}

Anderson, B. B. (1964). J. clin. Path., 17, 14.
Bichel, J. (1964). Acta med. scand., 176, 165.

Bull. Wld Hlth Org. (1964). Nomenclature for human immunoglobulins. 30, 447.

Dacie, J. V., and White, J. C. (1949). J. clin. Path., $2,1$.

Deller, D. J., and Witts, L. J. (1962). Quart. J. Med., 31, 71.

Drivsholm, A. (1964). Acta med. scand., 176, 257.

Forshaw, J. (1963). Brit. med. J., 2, 101.

Gabuzda, T. G. (1962). J. Lab. clin. Med., 59, 65.

Gibbs, D. D., and Pryor, J. S. (for Rusby, N. L.) (1961). Proc. roy. Soc. Med., 54, 590.

Girdwood, R. H. (1953). Brit. med. J., 2, 741.

Hansen, H. A. (1964). On the Diagnosis of Folic Acid Deficiency, p. 90. Almqvist and Wiskell, Stockholm.

Heilmeyer, L., and Begemann, H. (1951). Blut und Blutkrankheiten (Handbuch der inneren Medizin, 4th ed., vol. 2.). Springer Verlag, Berlin.

Hobbs, J. R. (1965). Nature (Lond.), 207, 292.

- Slot, G. M. J., Campbell, C. H., Clein, G. P., Scott, J. T., Crowther, D., and Swan, H. T. (1966). Lancet, 2, 614.

Hoffbrand, A. V., Newcombe, B. F. A., and Mollin, D. L. (1966). J. clin. Path., 19, 17.

Horrigan, D. L., and Heinle, R. W. (1952). J. Lab. clin. Med., 40, 811. Killander, A., and Larsson, S. O. (1962). Proc. 8th Congr. europ. Soc. Haemat., pt. 2, p. 334. S. Karger, Basel.

Klayman, M. I., and Brandborg, L. (1955). New Engl. J. Med., 253, 808.

Lampkin, B. C., Shore, N. A., and Chadwick, D. (1966). Ibid., 274, 1168.

Larsson, S. O., (1962). Acta med. scand., 172, 195.

-, Hagelquist, E., and Cöster, C. (1961). Acta haemat. (Basel.), 26, 50.

Lee, F. I., Jenkins, G. C., Hughes, D. T. D., and Kazantzis, G. (1964). Brit. med. J., 1, 598.

Mandema, E. (1956). Over het multipel myeloom, het solitaire plamocytoom en de macrocytobulinaemie. Dijkstras Drukherij, Groningen.

—, Faber, J. G., de Vries, J. A., and Nieweg, H. O. (1956). Ned. T. Geneesk, 100, 3588.

Meyer, L. M., Bertcher, R. W., Cronkite, E. P., Suarez, R. M., Miller, I. F., Mulzac, C. W., and Olivarreta, S. T. (1961). Acta med. scand., 169, 557.

Mollin, D. L., and Ross, G. I. M. (1952). J. clin. Path., 5, 129.

- (1957). Vitamin $B_{1}$ und Intrinsic Factor. 1. Europäisches Symposion Hamburg 1956, edited by H. C. Heinrich, p. 4130. Enke, Stuttgart.

- Waters, A. H., and Harris, S. E. (1962). Vitamin $B_{12}$ und Intrinsic Factor. 2. Europäisches Symposion Hamburg 1961, edited by H. C. Heinrich, p. 737. Enke, Stuttgart.

Nathans, D., Fahey, J. L., and Potter, M. (1958). J. exp. Med., 108, 121.

Reisner, E. H., Jr. (1958). Blood, 13, 313.

Sandkühler, S. (1951). Dtsch. med. Wschr., 76, 168.

Schilling, R. F. (1953). J. Lab. clin. Med., 42, 860.

Swendseid, M. E., Swanson, A. L., Meyers, M. C., and Bethell, F. H. (1952). Blood, 7, 307.

Toušek, M., and Vortel, V. (1947). Cas. Lék. čes., 86, 1538.

van Dommelen, C. K. V., Olie, R. J., and Slagboom, G. (1964). Acta med. scand., 176, 611 .

Waters, A. H., and Mollin, D. L. (1961). J. clin. Path., 14, 335.

Wokes, F., Badenoch, J., and Sinclair, H. M. (1955). Amer. J. clin. Nutr., 3, 375. 